\title{
THE ROLE OF CORPORATE GOVERNANCE IN INDIAN BANKING COMPANIES
}

\author{
Dr.K.Thirumamagal \\ Principal in Charge \& Head, Department of Commerce (Accounting \& Finance) \\ S.S.K.V College of Arts \& Science for Women, Kizhambi, Kanchipuram
}

Article DOI: https://doi.org/10.36713/epra7041

DOI No: 10.36713/epra7041

\begin{abstract}
The process of liberalization and deregulation was unleashed by the new economic policy of the Government of India during 1991. Reforms in financial sector opened the doors to the private sector Banks in the country and it paved way for the new generation banks. Customers welcomed these financial institutions and they were awaiting for this opportunity to make themselves comfortable with the services provided by private sector banks after experiencing poor services from Nationalized Banks. The unethical practices and increased corruption kept the management of different organization to fleece their customers which in turn resulted in the closing down of some big companies. The need of Corporate Governance was felt during the securities scam of Harshad Mehta's in April 1992 involving a large number of banks and it resulted a drastic change for the first time in stock market that shook the confidence of investors. The practices of the Corporate Governance has to be constantly evaluated because of the uncertain and complex business environment in India.
\end{abstract}

KEY WORDS: Banking Companies, Fraud, Scams, Corporate Governance

\section{INTRODUCTION}

A sloka from Rig-Veda says "A Businessman should benefit from business like a honey bee which suckles honey from the flower without affecting its charm and beauty. In today's scenario, they are sucking not only the honey from the flower but also faith, the customers have in them. To boost and uplift the confidence of investors, the Corporate Governance entered India in 1997 with a voluntary code framed by the Confederation of Indian Industry (CII). Always there is a debate on ' what is a good governance?' is it about the job, obligations and responbilities to be carried out by an employee in an organization or it should focus on higher responsibilities, more regulations for board of directors, or increase in the activities of the shareholders. However there is no standard metrics to determine or measure the governance of banking companies to rate the governance as good or bad but it can be measured by the policies and process adopted by a banking company. If the corporate governance is effective, it will boost up the economy of a country which in turn will boost the confidence level of the stakeholders. The corporate Governance is nothing but the commitment to values, ethics in business, contribution towards social causes and considering the interest of all the stakeholder to have a fair conduct of business. It is considered to be an important tool for the socio economic development of the country. The corporate governance framework which needs to be followed by the company is presented in the form of a chart below. 
Chart 1.1

Corporate Governance Framework

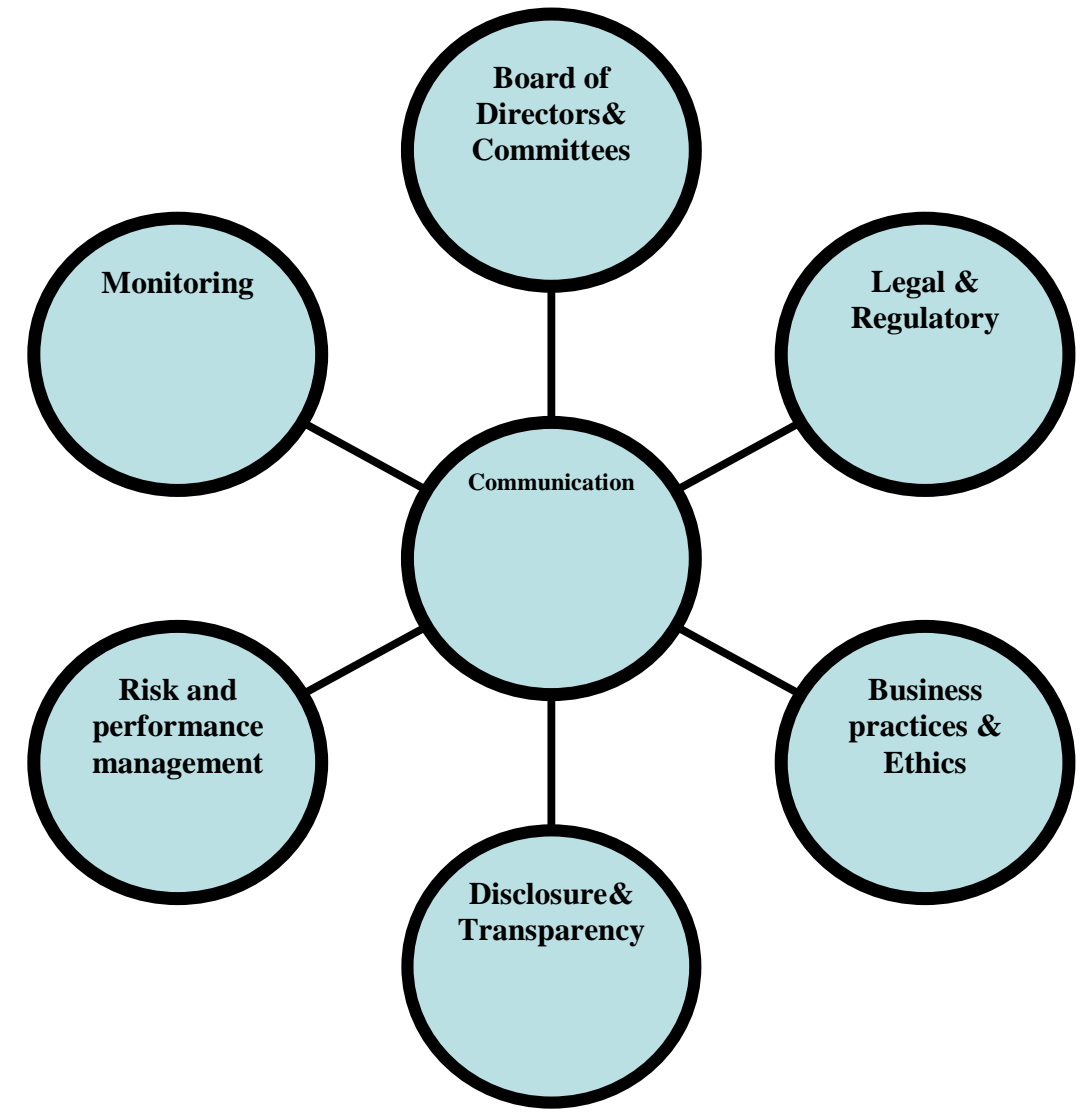

\section{OBJECTIVES OF THE STUDY}

The main objective of this study is

(i) To analyse the Corporate Governace Practices in Indian Financial Institutions

(ii) To examine the needs of Corporate Governance practices in Indian Financial Institutions.

(iii) to inculcate the parameters of corporate governance in to shareholders and stakeholders too. The parameters are their rights, their equitable treatment, their role, disclosure and transparency of company's day to day operations and the drastic changes that took place in the organizations. (iv) To suggest some remedial measures to the indian Financial Institutions while adopting corporate governance practices.

\section{METHODOLOGY OF THE STUDY}

The research methodology used is based on cluster sampling as the researcher has divided the total population in to clusters or groups and there by randomly selected from the group of samples based on convenience. The primary data is gathered by direct interaction with the people of the organization by means of verbal discussion. The secondary data sources are the banking company manuals, previous reports and websites. 


\section{SAMPLE SELECTION}

Table 1.1

Employees of Various Institutions

\begin{tabular}{|c|c|l|l|l|l|l|}
\hline Particulars & $\begin{array}{l}\text { Non Banking } \\
\text { Finance } \\
\text { companies }\end{array}$ & \multicolumn{4}{|c|}{ Banking companies } & \\
\hline & & $\begin{array}{l}\text { Nationalized } \\
\text { banks }\end{array}$ & $\begin{array}{l}\text { Public } \\
\text { sector } \\
\text { banks }\end{array}$ & $\begin{array}{l}\text { Private } \\
\text { sectorbanks }\end{array}$ & $\begin{array}{l}\text { Foreign } \\
\text { banks }\end{array}$ & Total \\
\hline Total sample & $\mathbf{1 4 0}$ & 132 & 127 & 152 & 14 & $\mathbf{4 4 7}$ \\
\hline $\begin{array}{c}\text { No of } \\
\text { respondents }\end{array}$ & $\mathbf{3 2}$ & 16 & 22 & 54 & 2 & $\mathbf{1 2 6}$ \\
\hline
\end{tabular}

\section{LITERATURE REVIEW}

Arun and Turner (2002) discussed the theoretical analysis of corporate governance with regard to public sector banks in India, as particular. The researchers argued that interests of other stakeholders appear more important to it than in the case of non-banking organizations. In the case of banking, the risk involved for the depositors is less compared to the risk involved for the banking companies. They added that the Indian banking system is at greater strength because of the control of government and implementation of economic reform programme during 1991. Their observation is the corporate governance issues have not received much attention in the first generation of financial sector reforms. It has gained momentum only during the second decade of reforms in India.

Arun and Turner (2003) research is another good theoretical analysis of the corporate governance of banking institutions in developing economies. They suggested that the corporate governance of banks is severely affected by political considerations. Firstly he suggested providing ways to private sector banks by inculcating the ethics and values of business to the person who are the backbone of such banks. Secondly, he suggested the entry of foreign banks in the developed economies to provide stiff competition to the domestic banks thereby they will emulate the corporate governance practices of their foreign competitors.

Das and Gupta (2004) discussed and examined the issues of corporate governance in the Indian banking system. His datas include 27 public sector banks for the period 1996-2003, his findings include and revealed the fact that the CEO of the poor performing banks get a better return than the CEO of the well developed banks. He pointed out that corporate governance in Indian banks is perfect and good if each and everyone feel their responsibility. Machold and Vasudevan, (2004) investigated governance reforms in India over the last decade. He analyzed and revealed the mixed mechanisms of Indian governance with Anglo-American governance.

Goswami (2003) made a comprehensive study of the state of corporate governance in India. He almost all the area of corporate governance pointed out including the roots, corporate structure, regulatory environment $\&$ initiatives taken by the authority etc. He observed that India has made much more rapid strides in corporate governance than most its Asian counterparts and also in the next few years it will an greater flurry of activity by several factors such as competition, growth of market capitalization, foreign investors, and strong financial press. He also added that Indian corporations have appreciated the fact that good corporate governance and internationally accepted standards of accounting and disclosure can help them to access the US capital markets.

Boubakri et al., (2003) examined the corporate governance features and suggested the privatization of companies in order to attain the objectives of profitability and to create values for both shareholders and stakeholders

From the above foregoing analysis of the study it is revealed that corporate governance has recently become an issue of national concern across the world. It not only hinges on transparency and integrity but also it is considered as a engine to the economic growth of a country like India. Our country is a good example for other developing countries in the world for monitoring, regulating and implementing the corporate governance issues both in financial and non financial companies.

Adnan et al. (2011) examined the banks in Malaysia using a panel data analysis and suggested that smaller board size and higher percentage of ownership hasd lead to efficient banking.

Mang' Unyi (2011) investigated the performance of banks in Kenya with regard to the adoption of 
corporate governance practices and suggested that the bank which monitors and maintain the corporate governance over its policies and procedures has a efficient and effective functioning.

Pandya (2011) opines that there is a significant relationship between governance structures and firm performance. The author studies the effect of corporate governance structures, particularly board independence and CEO duality. Thomas et al. (2014) A Study on Corporate Governance Practices of Indian Financial Sector Companies 33 investigated the impact of corporate governance on performance of listed Indian banks by using a panel data analysis The research findings stated that a smaller board size, higher proportion of independent directors and a higher percentage of public ownership lead to better performance of Indian banks.

\section{THE THEORIES OF CORPORATE GOVERNANCE}

The following theories of Corporate Governance benefits the stakeholders of the companies and increases the transparency once it is adopted by the companies.

(i) The Agency Theory

(ii) The stakeholder Theory

(iii) The Resource Dependency Theory

(iv) The stewardship Theory

(v) The Enlightened Shareholders Theory

The agency theory is also referred as principal agent theory. According to this theory, principal is referred as the owners and the agents as managers and the board of directors will be monitoring the process adopted and carried out. There are two importance factors in this theory. One is the company will have only two participants i.e., the manager and the shareholder, whose ideas will always be clear and precise. The second factor is the humans are always self interested who will sacrifice their self interest for others. This theory makes the company to mitigate the agency problems to have a efficient market with effective control.

The stakeholder theory gives us information about the issues faced by the stakeholders in a company. it is also said that this theory is better in explaining the role of corporate governance by highlighting the differenent constituents of the firm than the agency theory.

The resource dependency theory stresses on the linkage which needs to be created by a company with the environment. In this theory board of directors play a pivotal role in reducting the transaction cost associated with environmental interdependency.

The stewardship theory is totally opposite to the agency theory. In this theory the managers will act as a steward who will act in the best interest of the owners. This theory shows the strong relationship between the manager and the success of the firm. The enlightened shareholders theory identifies and satisfies the interest of the shareholders of the firm. As there are different theories which can be adopted by a firm to have a good corporate governance there are also various models of different countries but only five models are identified with their world wide recognition. Each one has its own significance.

1. The Anglo US model

2. The German Model

3. The Japanese Model

4. The Asian Family Based Model

\section{CORPORATE GOVERNANCE IN INDIA}

The Confederation of Indian Industry|(CII) took initiatives with the objective developing a Code of conduct for indian banking and financial institutions after considering the importance of Cadbury Committee report of UK. In the year 1996, national task force was constituted by the CII under the chairmanship of shri Rahul Bajaj.

This committee came with major recommendations such as the directorship are limited to 10 listed companies at a time, 30\% professionally competent non Executive Director should be appointed by the company whose turnover is more than 100 crores a year. It has also become mandatory to set up audit committees. In order to raise the standard of Corporate Governance in India, another committee was constituted under the chairmanship of Kumar Mangalam Birla in the year 1999. This committee has given two segment of recommendations, one is mandatory recommendations and the other is non mandatory recommendations. Mandatory recommendations were on the policy framework and delegation of roles and responsibilities. Non Mandatory Recommendations were on the training of employees and whistle blower policies. In May 2020 another committee was framed by the Department of Corporate Affairs under the chairmanship of Dr.P.L.Sanjeev Reddy to develop further the culture of Corporate Governance in India. The following committees were also established to strengthen the corporate Governance system in India 
1. RBI Advisory Group on Corporate Governance - 2001

2. RBI Consultative Group of Directors of Banks/Financial Institutions - 2002

3. The Naresh Chandra Committee -2002

4. The Narayana Murthy Committee -2003

5. The J.J.Irani Committee -2005

6. The Central Coordination and Monitoring Committee

The institute of companies Secretary has also given reccommendations to strengthen the corporate governance framework in india. The best recommendations given by ICSI are as follows:

There should be clear information about the roles and responsibilities of the top officials to have balance of the power in the firm.

it has also said to have remuneration committee and the Nomination Committee Mandatory.

1. Independent directors to have maximum of six years term

2. Corporate compliance committee should be constituted by the public limited companies whose paid up capital is above 5 crores.

\section{CORPORATE SOCIAL RESPONSIBILITY}

The CSR is also framed under section 135 of Companies Act 2013. It has also been recommended to frame a CSR committee by the companies whose networth is above 500 crores or more to formulate and monitor the CSR policies of the company.

Role of RBI in ensuring Corporate Governance in Banks

The RBI inspects and monitors the banks through CAMELS approach. It follows the guidelines given by the Board of Financial Supervision(BFS). The RBI follows three parameters in managing and maintaining effective corporate governance

1. Prompt disclosure and transparency norms
2. Off site survelliance

3. Timely appropriate and corrective action

The Basel committee was set up in the year 1975 by the central Governers of the G10 developed countries. It has given 12 principles of corporate governance for banks

1. Role of supervisors

2. Board of Directors overall responsibilities

3. Board qualification and composition

4. Board own structure and practice

5. Disclosure and Transparency

6. Compensation

7. Senior Management

8. Internal Audit

9. Compliance

10. Risk communication

11. Risk identification, monitoring and controlling

12. Governance of Group structure management functions

From the Verbal discussions from the employees of the banking companies the researcher came to know about the transparency in norms, administration and the banking frauds in small amounts are not taken seriously and also more pressure is given to the customers who avail loan and not repaying it on time. The employees working in banking companies also doesn't have clear idea about the policies and procedures to be followed in their day to day working. Based on the various recommendations of the committee, $60 \%$ of its suggestions is on the proportion of board of directors and independent directors, no of board meetings to be conducted and drafting various committees and the measures taken towards whistle blower policies. These are considered to be a cornerstone for practicing good corporate governance in financial institutions. The researcher has taken eight public sector banks and five private sector banks on the basis of market capitalization for the year 2019-20 which is presented below in a table

Table 1.2 Market Capitalisation and no of employees in the top position and the details of the board meeting for the year 2015-16

\begin{tabular}{|l|c|c|c|c|c|}
\hline \multicolumn{1}{|c|}{ Name of the bank } & $\begin{array}{c}\text { Market } \\
\text { Capitalisation }\end{array}$ & $\begin{array}{c}\text { Total no of } \\
\text { directors }\end{array}$ & $\begin{array}{c}\text { Non } \\
\text { executive } \\
\text { excluding } \\
\text { chairman) }\end{array}$ & $\begin{array}{c}\text { Independent non } \\
\text { executive }\end{array}$ & $\begin{array}{c}\text { No of board } \\
\text { meetings }\end{array}$ \\
\hline State Bank of India (SBI) & 1521919 & 14 & 5 & 4 & 12 \\
\hline Punjab National Bank (PNB) & 336636 & 11 & 3 & 4 & 13 \\
\hline Bank of Baroda (BoB) & 336502 & 10 & 2 & 4 & 13 \\
\hline Central Bank of India (CBI) & 73758 & 13 & 3 & 6 & 13 \\
\hline Dena Bank (DB) & 28530 & 12 & 3 & 6 & 10 \\
\hline United Bank of India (UBI) & 28357 & 9 & 2 & 4 & 10 \\
\hline Punjab and Sindh Bank (PSB) & 27325 & 10 & 2 & 5 & 9 \\
\hline
\end{tabular}

(c) 2021 EPRA EBMS | www.eprajournals.com 


\begin{tabular}{|c|c|c|c|c|c|}
\hline State Bank of Mysore & 23573 & 12 & 3 & 6 & 6 \\
\hline \multicolumn{6}{|l|}{ Private Sector Banks } \\
\hline HDFC Bank Ltd. (HDFC) & 1134625 & 11 & 6 & 7 & 7 \\
\hline ICICI Bank Ltd. (ICICI) & 1025805 & 13 & 7 & 7 & 10 \\
\hline Axis Bank (AB) & 18546 & 13 & 7 & 8 & 5 \\
\hline DCB Bank Ltd. (DCB) & 11672 & 13 & 11 & 10 & 7 \\
\hline $\begin{array}{lccc}\begin{array}{l}\text { Lakhsmi } \\
\text { (LVBL) }\end{array} & \text { Vilas } & \text { Bank } & \text { Ltd. } \\
\end{array}$ & 8367 & 12 & 11 & 6 & 12 \\
\hline
\end{tabular}

The above data shows us the details of the banks with market capitalization and no of employees holding the top positions. The corporate governance is much more than complying with legal and regulatory requirements. As per section 149(1) of The Companies Act 2013 there should be maximum of 15 directors in a company. the company may also appoint more than 15 directors after passing a special resolution. In the above table all the banks comply in accordance with the act. It has also been passed in the companies act that out of 15 directors there should be women directors too. The State Bank of India have not appointed women directors until 2013. The percentage of executive directors should be atleast 50\% compared to the Board of Directors in the company. it is also in accordance with the act as per the above table. if the board of meetings is for every month then it is a sign of proactive management. In the above table most of the bank conducted more than 10 meetings a year. But still there are scams and frauds which lead to the decline in our economic growth. Most of the banks in India requires recapitalization in order to follow Basel Norms. It involves raising of funds where the corporate governance practice plays a pivotal role. The bank has to put its utmost effort to meet both the mandatory and non mandatory requirements suggested by the Basel Norms.

\section{AN OVERVIEW OF THE FINANCIAL CRISIS AND CORPORATE SCANDALS}

After Harshad Mehta's case, there was a sudden growth of scam cases. In 1993, Investors lost roughly INR 5,000 crores when transnational companies allotted the equity shares to their respective controlling groups at steep discount to their market price in order to consolidate their ownership. Many companies vanished without any profile during 1993-94. In 199596, Investors were cheated up to INR 50000 crores by the plantation companies who mopped up this from gullible investors who believed investing in plantation would yield them huge returns. This was followed by the Mutual Fund Scam between 1995-98 by promising huge fixed return. Another big scandal happened with the help of Harshad Mehta in the Videocon price rigging case. One of the scam that too away the faith and total confidence level of the customers, they had in companies was the satyam scandal, worst compared to the previous scams here and elsewhere in the world. The promoters of the country's fourth largest IT Company systematically siphoned off billions of rupees of shareholders wealth. Even the most admired company Infosys Technologies with highest ethical standards was pulled down by phaneesh Murthy's case. Ramesh Gelli one of the promoters of the Global Trust Bank, a banking genius behind the success of it for more than 5 years. But within 10 years of its existence in 2003, it got in to all sort of regulatory hassles. The RBI, regulatory authority of India has to protect the depositors. After approaching various banks for merger, it finally zeroed in on Oriental Bank of Commerce as its NPA level had come down drastically. The scams in india started increasind day by day. Only the scandals of corporates came in to limelight such as $2 \mathrm{G}$ spectrum, Rotomac bank fraud, Punjab national bank fraud, etc., but the scams like Noida Ponzi scheme scam,delhi CNG scams not even in the news and people are not aware of the various scams which is happening around them. The scams by corporates also get vanished within 2 to 3 days of the news in the media. The major drawback of this scandal is negligible portions of share capital are owned by the promoter's families and rule the companies as if they are their personal fiefdoms. Why the industries entered the scenario with a lot of fanfare and hype and left out without any trace of them is because of the unethical practices and illegal tactics of our genius Indian corporates 
CHART 1.2

Corporate Governance practices

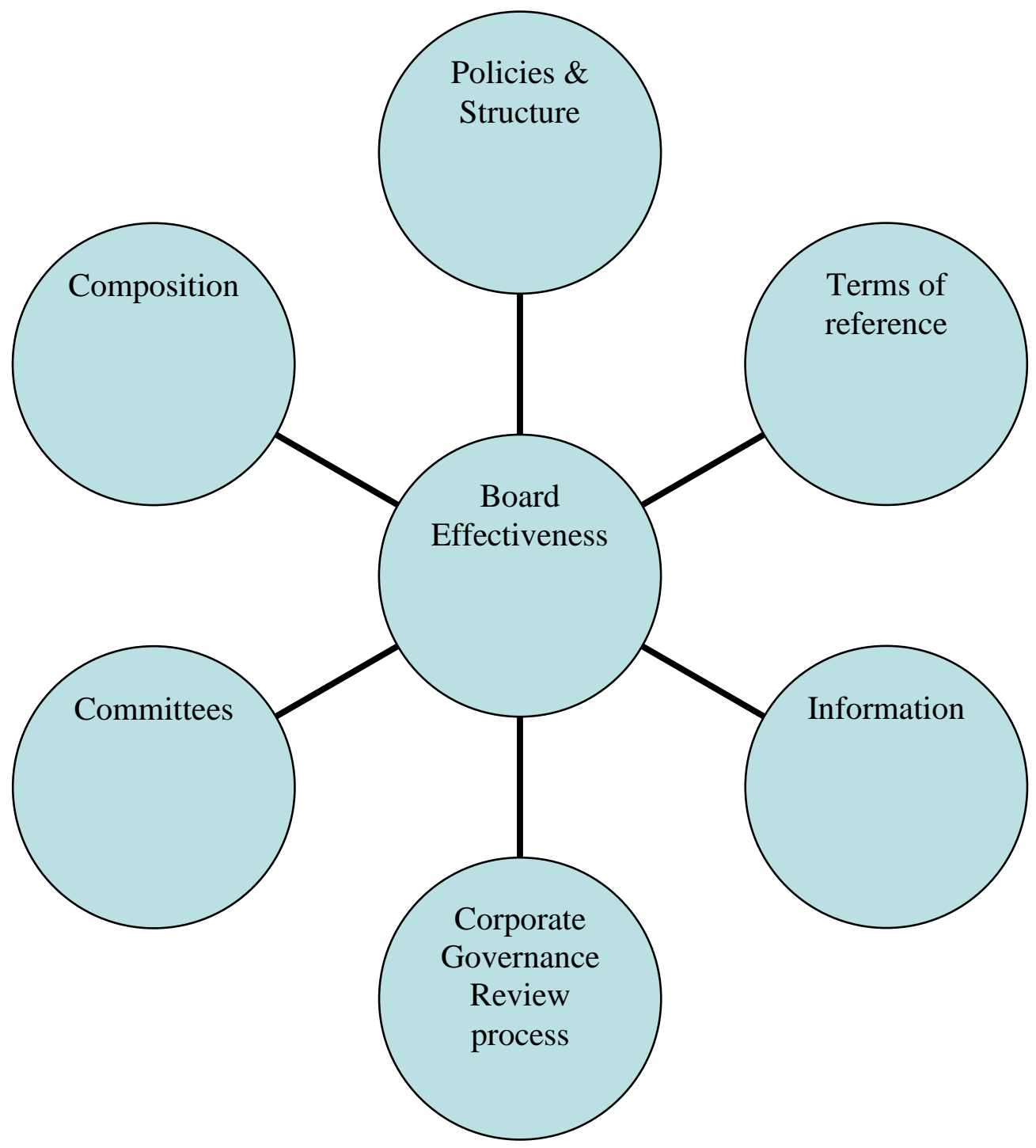

THE CORRUPTION INDEX OF INDIA FROM 2010 TO 2020

Table 1.3

\begin{tabular}{|c|c|c|c|c|c|c|c|c|c|c|c|}
\hline YEAR & $\mathbf{2 0 1 0}$ & $\mathbf{2 0 1 1}$ & $\mathbf{2 0 1 2}$ & $\mathbf{2 0 1 3}$ & $\mathbf{2 0 1 4}$ & $\mathbf{2 0 1 5}$ & $\mathbf{2 0 1 6}$ & $\mathbf{2 0 1 7}$ & $\mathbf{2 0 1 8}$ & $\mathbf{2 0 1 9}$ & $\mathbf{2 0 2 0}$ \\
\hline RANK & 84 & 95 & 94 & 94 & 85 & 76 & 79 & 81 & 78 & 80 & 86 \\
\hline
\end{tabular}




\section{CHART 1.3}

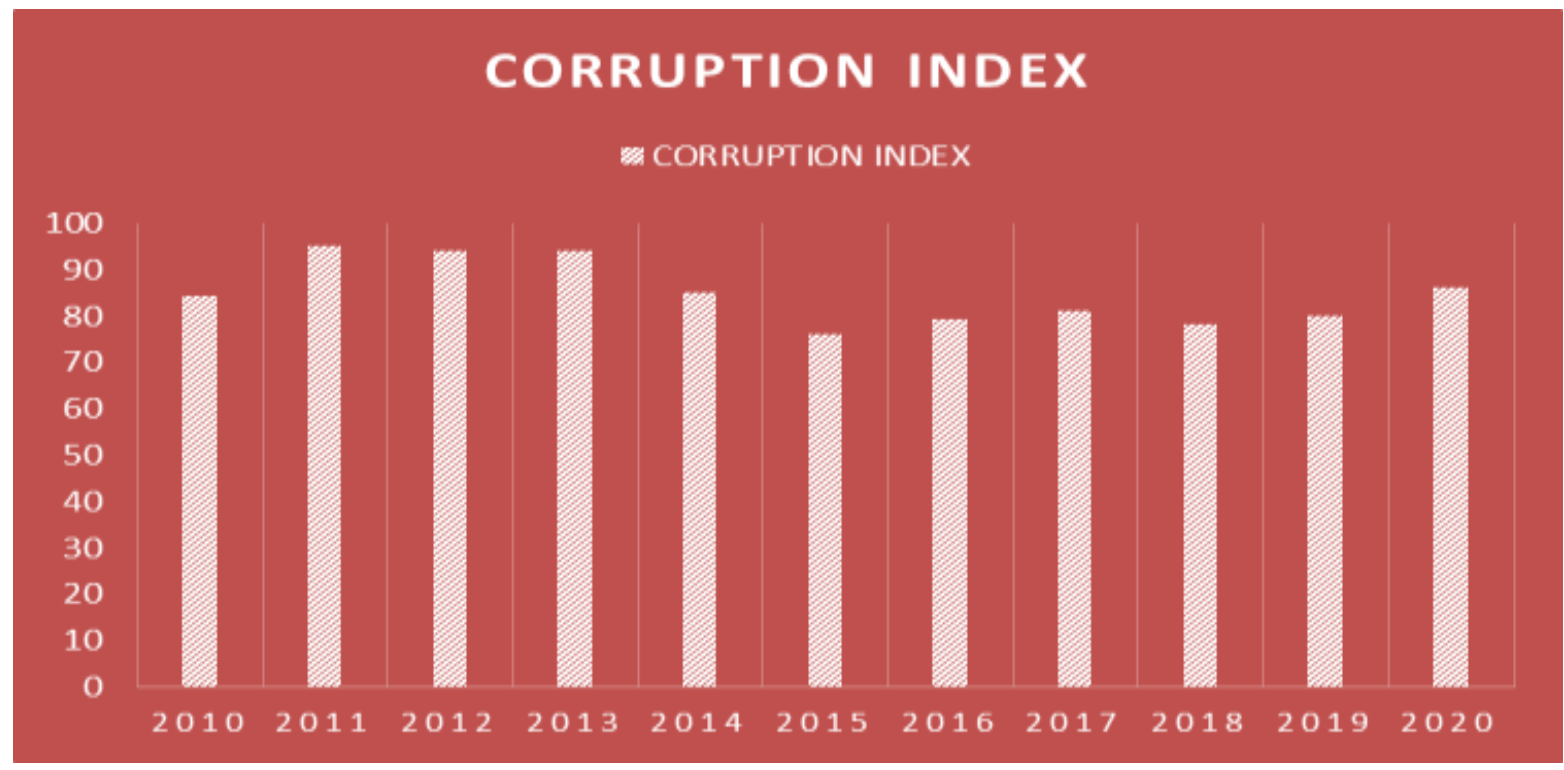

Source: Trading Economics.com

The Corruption Perception Index measures the perceived level of public sector corruption in 180 countries and territories around the world. The researcher has presented corruption index of India with regard to their ranks.. India was ranked 84 with score of 3.3 when Satyam Scandal took place during 2009, then it came down to 95 with a score of 3.1 during 2011 and now our country is at the place of 86 .

CPI source data captures the following aspects of corruption,

- Bribery

- Diversion of public funds

- Prevalence of officials using public office for private gain without facing consequences

- Ability of governments to contain corruption and enforce effective integrity mechanisms in the public sector

- Red tape and excessive bureaucratic burden which may increase opportunities for corruption

- Meritocratic versus nepotistic appointments in the civil service - Effective criminal prosecution for corrupt officials

- Adequate laws on financial disclosure and conflict of interest prevention for public officials

- Legal protection for whistleblowers, journalists, investigators when they are reporting cases of bribery and corruption
- State capture by narrow vested interests Access of civil society to information on public affairs

\section{KEY COMPONENTS OF CORPORATE GOVERNANCE}

After all these scams, Corporate Governance took its fame mostly in all the sectors. Bad Governance is the root cause for all these corruptions. The key requirement of good governance is the clarity on the roles and responsibilities of the top officials in the organization and it should be documented in a charter which can be followed throughout its perpectual succession. A Good Audit committee can also be drafted by the company to have a review on the adequacy of the internal control, and about the compliance with the policies and procedures followed by the company. Whistler blower policy has to be adopted where by the employees of the company can be given confidence on reporting the fruads, unethical behaviours or violation of the rules of the company. The company should have a healthy management which should emphasize on clear objectives and ethical framework and unambiguity of rules and regulations has to be maintained in all areas of manangement. . Good Corporate Governance are in born culture but are made by the combined effort of each and every person who engage themselves in the activities of the company. It enhances higher possibilities in delivering good business performance In India, we have companies that have shown a commendable success 
after following Corporate Governance Principles are Infosys Technologies Ltd, Tata Steel which is recognized and rewarded not only in India but also globally for its excellent corporate governance principles and its commitment towards social concern. Its vision statement tells us its commitment towards the society.

"To seize the opportunities of tomorrow and create a future that will make us an EVA positive company. To continue to improve the quality of life of our employees and the communities we serve.

It also emphasis the company to survive at its crucial phase in this competitive environment. It also ensures greater security for the investors in the company. it has also been found out from the company's data that the global financial investors are interested to invest in companies which has a good corporate goverenance which made the company to have good financial records.

\section{REQUIREMENTS OF CORPORATE GOVERNANCE INCOMPANIES}

The Rights given to Shareholders in the company are said to be the first requirement of corporate governance. The right of shareholders includes security for the ownership of their shares, right to vote, right to get full disclosure of information, right to involve or participate in decision with regard to sale or in amalgamation, absorption or external and internal reconstruction of companies. They have the right to know about the capital structure of the company which will make them to control their holdings. The next requirement of corporate governance is their equitable treatment with their foreign shareholders. Each and every shareholder has the right to redress the grievance. Insider trading should be strictly prohibited in order to provide equitable treatment. The stakeholders should be taken in to consideration apart from the shareholders because they are important as that of shareholders who perform and make decisions for eg. Bank, bondholders and workers. Apart from providing and recognizing their rights, employees should be allowed to represent themselves on board of directors, profit sharing, involvement of creditors during the proceedings of insolvency. In order to have active participation in the affairs of company, they should be ensured of correct access of information.

\section{CONCLUSIONS AND SUGGESTIONS}

A Company has to fame not only by with its networth but for its Corporate Social Responsibility, for its ethical practices and its involvement in empowerment of society. It should build a nation by providing its people all possible facilities to lead a life of ease and comfort. Public sector banks need to fundamentally strengthen institutional skill levels, strengthening human capital will be the single biggest challenge. Banks could reach the next level of their growth in Indian Banking Sector by continuing to innovate and develop differentiated business entrepreneur to profitably serve segments of the society; actively adopting acquisition as a means to grow and reaching the next level of performance in their service platforms. The extent to which Indian policy makers and bank managements develop and execute such a clear and complementary agenda to tackle Emerging discontinuities will lay the foundation for a high performing sector in 201 and will make our entrepreneurs to march ahead in this globalised world.

\section{REFERENCES}

1. Adnan, M. A., Htay, S. N. N., Rashid, H. M. A., \& Meera, A. K. M. (2011). A Panel Data Analysis on the Relationship between Corporate Governance and Bank Efficiency. Journal of Accounting. Aebi

2. Arun T.G and J.Turner(2005) Corporate Governance of Banks in developing Economies Concepts \& issues. Corporate Governance, An international Review, 12(3) 371,7

3. Benedikter, R. "Answers to the Economic Crisis: Social Banking and Social Finance”. Spice Digest, New York: Springer. (2011).

4. Fernando, A. C. "Business Environment". Noida: Dorling Kindersley (India) Pvt. Ltd. (2011)

5. Goyal, K. A. and Joshi, V. "Mergers in Banking Industry of India: Some Emerging Issues".Asian Journal of Business and Management Sciences, 1(2): 157-165, $2011 a$.

6. International Journal of Economics \& Research, 2011 2(5): 49-57, $2011 b$.

7. Pandya, H. (2011). Corporate Governance Structures and Financial Performance of Selected Indian Banks. Journal of Management \& Public Policy, 4.

8. Kulawczuk p.1998. The Development of entrepreneurship in rural areas.

9. Mang'unyi, E. E. (2011). Ownership structure and Corporate Governance and its effects on performance: A case of selected Banks in Kenya. International Journal of Business Administration, 2(3), p2. Marinc

10. Reserve Bank of India (2014) Guidelines for Licensing of Payments Banks, dated November 27, 2014, RBI, Mumbai. Reserve Bank of India (2015) Master Circular - "Non-Banking Financial Companies - Corporate Governance (Reserve Bank) Directions, 2015", date: July 01, 2015, RBI, Mumbai.

11. SEBI (2015) Securities and Exchange Board of India (Listing Obligations and Disclosure Requirements) Regulations, 2015.

12. Sekaran, $U$. "Paths to the job satisfaction of bank employees". Journal of Organizational Behavior, 10(4): 347-359, 1989. 
13. Shrieves, $R$. E. "The relationship between risk and capital in commercial banks". Journal of Banking \& Finance, 16(2): 439-457, 1992.

14. Thomas R. and S. S. Thakur (2014) Analysis of Corporate Governance and Performance of Indian Banks, Shodh Ganga, Volume 4, No. -1, Jan.-Dec. 2014. Tricker "What RBI says about new banks?" Financial Express 12 Aug. 2010. General One File. Web. 17 Jan. 2013.

15. Wolgast, $M$. "M\&As in the financial industry: $A$ matter of concern for bank supervisors?" Journal of Financial Regulation and Compliance, 9(3): 225-236, 2001 